\title{
A Study on Effectiveness of Structured Teaching among Nursing Students
}

\author{
Priyanka Chaudhary* \\ Department of medical surgical nursing, Guru Hargovind College of Nursing, Raikot, India \\ *Corresponding author
}

\begin{tabular}{|l|}
\hline Key w or d s \\
Knowledge, Basic \\
Life Support, \\
Structured Teaching \\
Programme \\
\hline Article Info \\
\hline Accepted: \\
18 May 2018 \\
Available Online: \\
10 June 2018 \\
\hline \hline
\end{tabular}

A B S T R A C T

The present study was conducted to assess the Effectiveness of Structured Teaching among Nursing Students regarding Basic Life Support (BLS) in Selected Colleges of Nursing, Ludhiana Punjab. The objective of the study were To assess the pre-test knowledge score regarding basic life support among nursing students in control and experimental group, To assess the post -test knowledge score regarding basic life support among nursing students in control and experimental group, To compare the pre and post-test knowledge score regarding basic life support among nursing students in control and experimental group, To find out the relationship between the pre and post-test knowledge score regarding basic life support among nursing students in control and experimental group with selected variables i.e. Age, Habitat, Clinical posting, Area of clinical exposure to B.L.S, Duration of clinical exposure and Source of Information. The conceptual framework of study was based on 'Ludwig Von Bertalanffy 1968'. This theory describe about input, throughput, output and feedback. The research approach adopted for this study was quasi experimental (non- equivalent control group pretestposttest design). Investigator selected a sample of 60 nursing students, 30 for experimental group and 30 for control group by using purposive sampling technique. The independent variables included in the study are Age, Clinical Posting, and Area of Clinical Exposure, Duration of Clinical Exposure, habitat and Source of Information. Structure Teaching on basic life support. The dependent variable was knowledge score regarding basic life support among nursing students. A structured multiple choice questionnaire was prepared to assess the knowledge among nursing students regarding basic life support. The tool consists of following three parts:- first part consisted of demographic data, second part consists of structured multiple choice questions to assess the knowledge of nursing students regarding basic life support third part consisted of structure teaching,. Descriptive and inferential statistics was used to analyze the data. Bar diagrams were used to depicts the finding. The study findings were the pre- test mean knowledge score in control and experimental group were $(17.80,17.13)$ and post- test mean knowledge score were $(17.43,27.03)$ it was inferred that post -test mean knowledge score was high in experimental than in the control group. Majority of the nursing students in control and experiment group had average pre test knowledge score 22(77.34\%), $16(53.34 \%)$. In experimental group majority of nursing students $20(66.66 \%)$ had good knowledge score and 4(13.34\%) had excellent knowledge score, $6(20 \%)$. So it was inferred that teaching had a definite impact on knowledge of nursing students regarding basic life support. Independent Variables had no impact on knowledge regarding basic life support. Based on the results of the study the following recommendations have been made for further study. A study can be replicated on large scale to validate and generalize the findings, similar study can be conducted on different settings like community and hospitals, A comparative study can be conducted on knowledge and skills of nurses in government and private hospitals, A similar study can be conducted by true experimental approach, A true experimental study can be conducted by using the STP for educating the paramedical professionals and even special groups like people working in factories, transports etc., An exploratory study can be done to assess the knowledge and practice of staff nurses regarding basic life support. 


\section{Introduction}

Cardiac arrest is often caused by abnormal heart rhythm called ventricular fibrillation (V.F). When ventricular fibrillation develops, the heart quivers and doesn't pump the blood. The victim V.F cardiac arrest needs cardiopulmonary resuscitation (C.P.R) and delivery of a shock to the heart called defibrillation. Defibrillation eliminates the abnormal ventricular fibrillation heart rhythm and allows the normal rhythm to resume.

Defibrillation is not effective for all form of cardiac arrest but it is effective to the ventricular fibrillation, the most common cause of sudden cardiac arrest. C.P.R is emergency procedure used to treat victims of cardiac and respiratory arrest. It is done with great urgency to avoid the brain damage or death results from 4-6 min without oxygen. (Araujo et al., 2011). Basic life support is that particular phase of emergency cardiac care that externally supports the circulation and ventilation of the victim of cardiac arrest or respiratory arrest through cardio pulmonary resuscitation. The main aim is to provide basic life support and save life of the patient, maintain an open and clear airway, breathing by artificial ventilation, blood circulation by external cardiac massage, also provide oxygen to the vital organs until appropriate definitive medical treatment arrives. Indication for the basic life support is respiratory arrest resulting from stroke, foreign body aspiration, airway obstruction, smoke inhalation, myocardial infarction and cardiac arrest. (Arnold broom, 2002)

\section{Statement of the problem}

A Quasi Experimental study to assess the Effectiveness of Structured Teaching among nursing students regarding Basic Life Support (BLS) in selected colleges of nursing, Ludhiana Punjab

\section{Aim of the study}

The aim of the study is to assess the Effectiveness of Structured Teaching programme on Basic Life Support (BLS) among B.Sc. (N) $2^{\text {nd }}$ year students with a view to improve knowledge regarding basic life support.

\section{Objectives}

To assess the pre-test knowledge score regarding basic life support among nursing students in control and experimental group.

To assess the post -test knowledge score regarding basic life support among nursing students in control and experimental group

To compare the pre and post-test knowledge score regarding basic life support among nursing students in control and experimental group.

To find out the relationship between the pre and post-test knowledge score regarding basic life support among nursing students in control and experimental group with selected variables i.e. age, habitat, clinical posting, area of clinical exposure to B.L.S, duration of Clinical Exposure and Source of Information.

\section{Research Hypothesis}

$\mathrm{H}_{1}$ The Posttest mean knowledge score of nursing students in experimental group regarding basic life support will be significantly higher than mean knowledge score of nursing students in control group as measured by self-structured questionnaire at $\mathrm{p}<0.05$ level

\section{Conceptual frame work}

Conceptual frame work was developed on the basis of open system theory given by Ludwig 
Von Bertalanffy (1968). In this system each individual is considered as an open system to the environment that gets input in the form of energy, matter and information which ultimately changes the cognition level of the individual and shows impact on knowledge score.

\section{Independent variable}

The independent variables included in the study were age, habitat, clinical posting, area of exposure to basic life support, duration of Clinical Exposure and Source of Information.

\section{Dependent variables}

The dependent variables were knowledge regarding basic life support among nursing students

\section{Description of the tool}

A self-structured multiple choice questionnaires was prepared to assess the knowledge of nursing students regarding basic life support, the review of literature, expert's opinion and investigator's own experience provided the basis for construction of the tool.

The tool consisted of the following three parts:

\section{Content validity of the tool}

Content validity was done by expert's opinion. The tool was calculated to 16 experts of various specialties

\section{Reliability}

Reliability was computed by applying Split Half method and calculated by Karl Pearson's Coefficient of correlation \& spearman's brown prophecy formula. The reliability was found to be 0.9. Hence the tool was reliable

\section{Review of literature}

\section{Studies related to cardiac arrest}

White L et al., (2010) conducted a study on Dispatcher-assisted cardiopulmonary resuscitation: risks for patients not in cardiac arrest reveals that the frequency of serious injury related to dispatcher-assisted bystander CPR among non-arrest patients was low. When coupled with the established benefits of bystander CPR among those with arrest, these results support an assertive program of dispatcher-assisted CPR.

\section{Studies related to knowledge of BLS and CPR}

Araujo S. et al., (2011) conducted the descriptive study to analyze the theoretical knowledge of nurses working in non-hospital urgent and emergency care. These units concerning cardiopulmonary arrest and resuscitation. A questionnaire was applied to 73 nurses from 16 units in seven cities in the region of Campinas, SP, Brazil. The respondents displayed some gaps in their knowledge such as how to detect Cardiopulmonary Arrest (CPA), the ability to list the sequence of basic life support, and how to determine the appropriate compression to ventilation ratio $(>60 \%)$. They also did not know: the immediate procedures to take after CPA detection $(>70 \%)$; the rhythm pattern present in a CPA (>80\%); and they only partially identified $(100 \%)$ the medication used in cardiopulmonary resuscitation. The nurses presented partial knowledge of the guidelines available in the literature.

\section{Studies related to Effectiveness of structured Teaching programme}

Tom Sirmons (2011) conducted the study, a across methods design was used, including two phases. In Phase 1, 100 post-primary 
students from three schools undertook the 'Save a Life' programme. Using pre and posttests, a questionnaire was given to students before and after training to evaluate their knowledge, attitudes, willingness and anxieties towards performing CPR/AED. After the programme, students' CPR/AED psychomotor skills were assessed in a simulated cardiac arrest scenario using a Resusci-Anne manikin and the Laerdal PC skills reporting system. In Phase 2, focus group interviews were conducted with nursing students to explore their experiences of the service learning experience. Informed consent was obtained from both the school students and the nursing students and ethical approval was secured.

\section{Research approach and rationale}

The research approach of the study was quasi experimental. This approach involves manipulation but lack at least one of the other two properties of true experiment i.e. randomization or control. The present study lacks randomization. Attempt has been made to assess the effectiveness of structure teaching programme on basic life support among nursing students.

\section{Research design}

The term research design refers to the development of plan or strategy that is accurate and objective which would guide the collection and analysis of data. It maximizes the control of investigator over the research situation. The independent variables included in the study were Age, Habitat, Clinical posting, Area of clinical exposure to B.L.S, Duration of clinical exposure and Source of Information and Structure Teaching Programme on basic life support. The dependent variable was knowledge score regarding basic life support among nursing students.

\section{Selection and description of setting}

The study was conducted at two nursing colleges. The nursing students for experimental group were taken from Guru Hargobind College of nursing, Raikot Ludhiana and control group was taken from Guru Tegh Bahadur Sahib College of nursing\& hospital, Ludhiana. Guru Hargobind College of nursing is situated at Raikot, Ludhiana. Total student strength of the college is 700. The total nursing students in B.Sc. (N) $2^{\text {nd }}$ year was 50. The college runs A.NM, G.N.M, Post- Basic B.Sc. Nursing, Basic B.Sc. Nursing, and M.Sc Nursing programs. Guru Tegh Bahadur Sahib College of nursing \& hospital, Ludhiana is situated at Shastri Nagar model town Ludhiana. Total student strength of the college is 600. The total nursing students in B.Sc. (N) 2nd year was 60 . The college runs G.N.M, Post- Basic B.Sc. Nursing, Basic B.Sc. Nursing, and M.Sc Nursing programs. Both the colleges are recognized under Baba Farid University of health sciences using the same syllabus. The distances between the two colleges are $40 \mathrm{~km}$. investigator selected two colleges to prevent contamination of tool. The reason for selecting these colleges was investigator's convenience and expected cooperation from authorities in getting permission for conducted the study.

\section{Population}

The population of the study was nursing students. Target population of the study consisted of nursing students from colleges of Guru Hargobind College of nursing is situated at Raikot, Ludhiana and Guru Tegh Bahadur Sahib College of nursing \& hospital, Ludhiana.

\section{Sample and sampling technique}

Investigator selected a sample of 60 nursing students, 30 for experimental group from Guru 
Hargobind College of nursing Raikot, Ludhiana and 30 for control group from Guru Tegh Bahadur Sahib College of nursing \& hospital, Ludhiana, by using purposive sampling technique. The nursing students in both experimental and control group were matched in relation to demographic data i.e. Age, Habitat, Clinical Posting, Area of Clinical Exposure, Duration of Clinical Exposure, and source of information.

\section{Inclusion Criteria and Exclusion Criteria}

\section{Inclusion Criteria}

B.Sc $2^{\text {nd }}$ year nursing Students

In selected nursing colleges, Punjab

\section{Exclusion Criteria}

B.Sc nursing 1 st, $3^{\text {rd }}$ and $4^{\text {th }}$ year students.

B.Sc $2^{\text {nd }}$ year nursing Students who are absent on that day

\section{Pilot study}

Pilot study was conducted during the month of February 2013, on 6 nursing students studying in selected colleges of nursing, Ludhiana. Permission taken from the principals of nursing colleges. The experimental group was taken from Nightingale College of nursing, narrangwal and control group was taken from Guru Nanak College of nursing, gopalpur. The distance between the two colleges was $15 \mathrm{~km}$. This procedure was done to ensure the reliability of tool \& feasibility of the tool.

The sample consists of 6 subjects 3 in experimental and 3 in control group Pretest of both experimental and control group was taken. The subjects in experimental group were given structured teaching on basic life support. Then posttest was taken third day from both the groups to assess the effectiveness of structured teaching programme. Time spend for structured teaching programme was 45 minutes.

\section{Data collection procedure}

\section{Permission}

A formal written permission was obtained from the principals of selected colleges after discussing the purpose and objective of the study with them. Also the nursing students were explained about the purpose of the study and confidentiality was assured to them. Verbal consent was taken from all the subjects for their participation of the study.

\section{Procedure}

The data collection procedure was carried out in the last week of February, 2013. The total group sample consists of 60 subjects, 30 in experimental and 30 in control group. The sample who were willing to participate and who were fulfilling the investigator's criteria was taken in the study. Purposive sampling technique was used for the selection of the samples.

Matching of the samples was done by matching all the independent variables taken for the study. To prevent the contamination experimental group was taken from Guru Hargobind College of nursing Raikot, Ludhiana and control group was taken from Guru Tegh Bahadur Sahib College of nursing $\&$ hospital, Ludhiana. Pre- test was taken from experimental and control group. The subjects in experimental group were then given to structure teaching on basic life support with the help of lesson plan and audio- visual aids.

Post-test was taken after sixth day from both the groups to assess the effectiveness of structured teaching programme. Time spend for structured teaching was 45 minutes 


\section{Analysis and Interpretation}

Analysis and interpretation was done in accordance with the objective laid down for study. The data was analyzed by calculating the score in the term of mean, mean percentage, standard deviation, ' $t$ ' value and ANOVA.

\section{Section - I Demographic Data}

Table 1: reveals that the subjects were studied by distributing them into various categories according to their age, habitat, clinical posting, area of exposure, duration of clinical exposure source of information.

The findings were as follows:

According to their age, in control group maximum 28 (93.33\%) nursing students were in the age group of 18- 20 years, followed by $2(6.67 \%) 21-23$ years. In the experimental group majority 26(86.67\%) nursing students were in the age group of 18-20 years, $4(13.33 \%)$ were in the age $21-23$ years.

According to habitat, in control group majority of 20(66.67\%) nursing students belonged to rural area and 10(33.33\%) from urban area. In experimental group majority of $19(63.33 \%)$ nursing students belonged to urban area and 11(36.67\%) from rural area.

As per clinical posting, in control group $30(100 \%)$ nursing students were posted in private hospital for clinical experience and in experimental group $30 \quad(100 \%)$ nursing students were posted in government hospital for clinical experience

Based on area of exposure in control group majority $21(70.00 \%)$ of nursing students had no exposure to basic life support. $4(13.33 \%)$ nursing student had exposed to basic life support in medical ward, 2(6.67\%) in I.C.U, 3
$(10.00 \%)$ in emergency. In experimental group majority of 23(76.67\%) nursing students had no exposure to basic life support. $2(66.7 \%)$ Nursing students had exposed to basic life support in medical ward, 2 (66.7\%) in I.C.U and $3(10.00 \%)$ in emergency.

With regard to duration of clinical exposure, in control group all 30 (100\%) nursing students had 7-9 month of clinical exposure and in experiment group $30(100 \%)$ nursing students had 4-6 month of clinical exposure.

According to source of information, in control group, $21(70.00 \%)$ nursing students had got information from curriculumlteachers. $5(16.67 \%)$ nursing students from health personnel, 4 (13.33\%) from mass media exposure. In experimental group, 23 (76.67\%) nursing students got information from curriculumlteachers. $\quad 3(10.00 \%)$ nursing student from health personnel, 4 (13.33\%) from mass media exposure.

Thus, it was concluded that in pre-test knowledge score both control and experimental group the nursing students had average knowledge score followed by below average. After the administration of structure teaching programme, there was high score in post -test knowledge score in experimental group as compare to control group.

Thus it was inferred that structure teaching had a definite impact on knowledge of nursing students regarding basic life support.

\section{Objectives}

To assess the pre-test knowledge score regarding basic life support among nursing students in control and experimental group.

To assess the post -test knowledge score regarding basic life support among nursing students in control and experimental group 
Table 2 depict, that in control group, the pretest mean knowledge score was 17.80 , mean percentage was 50.85 , post- test mean knowledge score was 17.43 and mean percentage was 49.8. In experimental group, the pre-test mean knowledge score was 17.13, mean percentage was 48.94. Post-test mean knowledge score was 27.03 , mean percentage was 77.22

Hence, it was inferred that post -test mean knowledge score was high in experimental group than in the control group.

Table 3 and fig. 3 explicit frequency and percentage distribution among nursing students according to the pre- test and posttest level of knowledge score regarding basic life support. In control group, majority of $22(74.34 \%)$ nursing student had average knowledge score, 8(26.66\%) below average and in experimental group, majority of nursing students $16(53.34 \%)$ had average pre- test knowledge score, 14(46.66\%) below average. None of the nursing students in both the control and experimental group had good or excellent knowledge in the pre test.

In control group, post- test knowledge score obtained by majority of nursing students $27(77.34 \%)$ had average knowledge score and $8(26.66 \%)$ students had below average knowledge score.

In experimental group majority of nursing students $20(66.66 \%)$ had good knowledge score and $4(13.34 \%)$ students had excellent knowledge score, 6 (20\%) students had average knowledge score. None of the nursing students in control group had good or excellent knowledge score.

Thus, it was concluded that in pre-test knowledge score both control and experimental group the nursing students had average knowledge score followed by below average. After the administration of structure teaching programme, there was high score in post -test knowledge score in experimental group as compare to control group.

Thus it was inferred that structure teaching had a definite impact on knowledge of nursing students regarding basic life support.

\section{Section III}

\section{Objective}

To compare the pre-test and post-test knowledge score regarding basic life support among nursing students in experimental and control group.

$\mathrm{H}_{1}: \mathrm{H}_{1}$ The Posttest mean knowledge score of nursing students in experimental group regarding basic life support will be significantly higher than mean knowledge score of nursing students in control group as measured by self-structured questionnaire at $\mathrm{p}<0.05$ level

Table 4 and fig 4:- delineate that in control group pre -test mean knowledge score was 17.80 and post -test mean knowledge score was 17.43. The difference between pre and post- test mean knowledge score of control group was statistically non- significant at $\mathrm{p}<$ 0.05 level.

In experimental group, the pre -test mean knowledge score was 17.13 and post -test mean knowledge score was 27.03. The difference between pre and post- test mean knowledge score of experimental group was statistically significant at $p<0.05$ and $p<0.01$ level.

Hence, research hypothesis $\left(\mathrm{H}_{1}\right)$ was accepted thus it was adjudged that structured teaching had definite impact on improving the knowledge among nursing students. 


\section{Objective 4}

To find out the relationship between the pre and post-test knowledge score regarding basic life support among nursing students in control and experimental group with selected variables i.e. age, habitat, clinical posting, area of clinical exposure, duration of Clinical Exposure and Source of Information.

Table 5 and fig. 5:- illustrate that in control group, maximum (17.79) pre-test mean knowledge score of nursing students was obtained by age group of 18-20 years, (18.00) in 21-23 years. And in post-test (17.39) mean knowledge score among nursing students was obtained by $18-20$ years, and (18.00) in 21-23 years. The difference between pre and post test mean knowledge score in control group of nursing students who were in various age group was statistically non-significant at $\mathrm{p}<0.05$ level. The difference among pre and post -test mean knowledge score was found statistically non-significant at $\mathrm{p}<0.05$ level computed by ANOVA.

In experimental group maximum (17.15) pretest mean knowledge score among nursing students was obtained by age group of 18-20 years, (17.00) in 21-23 years. And in post-test (28.50) mean knowledge score among nursing students was obtained by 21-23 years, and (26.81) in 18- 20 years. The difference between pre and post -test mean knowledge score in experiment group among nursing students according to age was statistically non-significant at $\mathrm{p}<0.05$ level. The difference among pre and post -test mean knowledge score was found statistically non-significant at $\mathrm{p}<0.05$ level computed by ANOVA.

Hence it is inferred that age had no impact on knowledge among nursing students. But structured teaching programme had a definite influence on their knowledge regarding basic life support.
Table no -6 and fig 6:- illustrate that in control group, maximum (17.95) pre-test mean knowledge score among nursing students was obtained who belonged from rural area, (17.50) from urban area. And in post-test (17.50) mean knowledge score among nursing students was obtained who belonged to rural area and (17.30) from urban area. The difference between pre and post -test mean knowledge score in control group among nursing students who belonged to rural and urban area was statistically non-significant at $\mathrm{p}<0.05$ level.

The difference among pre and post -test mean knowledge score was found statistically nonsignificant at $\mathrm{p}<0.05$ level computed by ANOVA.

In experimental group maximum (17.55) pretest mean knowledge score among nursing students was obtained, who belonged from rural area, (16.89) from urban area. And in post-test (26.18) mean knowledge score among nursing students was obtained who belonged to rural area and (27.53) from urban area. The difference between pre and post -test mean knowledge score in experiment group among nursing students who were in various age group was statistically significant at $\mathrm{p}<0.05$ level.

Hence, habitat had definite effect on knowledge score of nursing students as well as structured teaching programme had also definite influence on their knowledge regarding basic life support.

Table no 7 and fig. 7:- delineate that in control group pre -test mean knowledge score of nursing students (17.80) who were going to private hospital for clinical posting and post test mean knowledge score was 17.43. The difference between pre and post- test mean knowledge score of control group was statistically non- significant at $\mathrm{p}<0.05$ level. 
Table.1 Frequency and percentage distribution of demographic data

\begin{tabular}{|c|c|c|c|c|c|c|}
\hline \multirow[t]{2}{*}{ Demographic data } & \multicolumn{2}{|c|}{$\begin{array}{c}\text { Control group } \\
\quad \mathbf{n}=(\mathbf{3 0})\end{array}$} & \multicolumn{2}{|c|}{$\begin{array}{l}\text { Experimental group } \\
\qquad \mathbf{n}=(\mathbf{3 0})\end{array}$} & \multirow[t]{2}{*}{ d.f. } & \multirow[t]{2}{*}{$\mathbf{X}^{2}$} \\
\hline & n. & \%age & n & $\%$ age & & \\
\hline \multicolumn{7}{|l|}{ Age } \\
\hline $18-20$ & 28 & 93.33 & 26 & 86.67 & 1 & $0.75 \mathrm{NS}$ \\
\hline $21-23$ & 2 & 6.67 & 4 & 13.33 & & \\
\hline \multicolumn{7}{|l|}{ Habitat } \\
\hline Rural & 20 & 66.67 & 11 & 36.67 & & \\
\hline Urban & 10 & 33.33 & 19 & 63.33 & 1 & $5.41 *$ \\
\hline \multicolumn{7}{|l|}{ Clinical Posting } \\
\hline Private Hospital & 30 & 100.00 & 0 & 0.00 & & NA \\
\hline Govt. Hospital & 0 & 0.00 & 30 & 100.00 & - & \\
\hline \multicolumn{7}{|l|}{ Area of Exposure } \\
\hline Medical Ward & 4 & 13.33 & 2 & 6.67 & & \\
\hline Emergency & 2 & 6.67 & 2 & 6.67 & & \\
\hline ICU & 3 & 10.00 & 3 & 10.00 & 3 & $0.34 \mathrm{NS}$ \\
\hline No where & 21 & 70.00 & 23 & 76.67 & & \\
\hline \multicolumn{7}{|l|}{$\begin{array}{l}\text { Duration of Exposure } \\
\text { to BLS }\end{array}$} \\
\hline 4-6 months & 0 & 0.00 & 30 & 100.00 & & \\
\hline 7-9months & 30 & 100.00 & 0 & 0.00 & - & NA \\
\hline Above 9 months & 0 & 0.00 & 0 & 0.00 & & \\
\hline \multicolumn{7}{|l|}{ Source of Information } \\
\hline Curriculum/teachers & 21 & 70.00 & 23 & 76.67 & & \\
\hline Health Personnel & 5 & 16.67 & 3 & 10.00 & 2 & $0.34 \mathrm{NS}$ \\
\hline Mass Media & 4 & 13.33 & 4 & 13.33 & & \\
\hline
\end{tabular}

Table.2 Pre and posttest mean knowledge score regarding basic life support among nursing students in control and experimental group

\section{KNOWLEDGE SCORE}

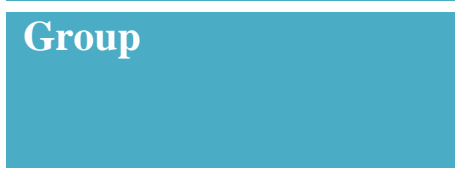

\section{Control}

Experimental

Maximum score $=35$

Minimum score $=0$

\begin{tabular}{|c|c|c|c|c|}
\hline \multicolumn{3}{|c|}{ Pre test } & \multicolumn{2}{c|}{ Post test } \\
\hline $\mathbf{n}$ & mean & mean\% & mean & mean\% \\
\hline 30 & 17.80 & 50.85 & 17.43 & 49.8 \\
\hline 30 & 17.13 & 48.94 & 27.03 & 77.22 \\
\hline
\end{tabular}


Table.3 Frequency and Percentage Distribution of Pre and Post Test Knowledge Score regarding basic life support among nursing students in Control and Experimental Group

\section{KNOWLEDGE SCORE}

\begin{tabular}{|c|c|c|c|c|c|c|c|c|c|}
\hline \multirow{3}{*}{$\begin{array}{l}\text { Level of } \\
\text { knowledge (\%) }\end{array}$} & \multirow[t]{3}{*}{ Score } & \multicolumn{4}{|c|}{ Control group $(n=30)$} & \multicolumn{4}{|c|}{ Experimental group $(n=30)$} \\
\hline & & \multicolumn{2}{|c|}{ Pre-test } & \multicolumn{2}{|c|}{ Post test } & \multicolumn{2}{|c|}{ Pre-test } & \multicolumn{2}{|c|}{ Post test } \\
\hline & & $\mathbf{n}$ & $\%$ & $\mathbf{n}$ & $\%$ & $\mathbf{n}$ & $\%$ & $\mathbf{n}$ & $\%$ \\
\hline Excellent $(\geq 88)$ & $\geq 31$ & - & - & - & - & - & - & 4 & 13.34 \\
\hline Good (71-85) & $25-30$ & - & - & - & - & - & - & 20 & 66.66 \\
\hline Average(48-68) & 17.24 & 22 & 77.34 & 22 & 77.34 & 16 & 53.34 & 6 & 20.00 \\
\hline $\begin{array}{l}\text { Below average } \\
(\leq 45)\end{array}$ & $\leq 16$ & 8 & 26.66 & 8 & 26.66 & 14 & 46.66 & - & - \\
\hline
\end{tabular}

Maximum score $=35$

Minimum score $=0$

Table.4 Comparison of Pre and Post Test Mean Knowledge Score regarding basic life support among nursing students in Control and Experimental Group

$\mathrm{N}=60$

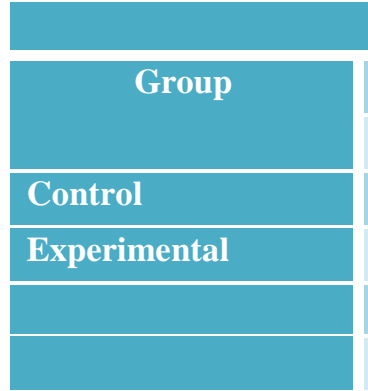

Maximum score $=35$

Minimum score $=0$

\section{KNOWLEDGE SCORE}

\begin{tabular}{|c|c|c|c|c|c|c|}
\hline & \multicolumn{2}{|c|}{ Pre-test } & \multicolumn{2}{c|}{ Post test } & df & 't' \\
\hline $\mathbf{n}$ & Mean & SD & Mean & SD & \\
\hline 30 & a17.88 & 12.50 & a'17.43 & 1.98 & 29 & $1.02^{\text {NS }}$ \\
\hline 30 & b17.13 & 2.58 & b'27.03 & 2.97 & 29 & $14.73^{*}$ \\
\hline & df & 't' & df & 't' & & \\
\hline a+b & 58 & 0.80 & a'+b' 58 & $15.05^{*}$ & & \\
\hline
\end{tabular}

$*$ Significant at $(\mathrm{p}<0.05)$

NS- non significant

Table.5 Comparison of Pre and Post Test Mean Knowledge Score regarding basic life support among nursing students in Control and Experimental Group According to Age

\begin{tabular}{|c|c|c|c|c|c|c|c|c|c|c|c|c|c|c|}
\hline \multicolumn{15}{|c|}{ KNOWLEDGE SCORE } \\
\hline \multicolumn{7}{|c|}{ Control group $(\mathrm{n}=\mathbf{3 0})$} & \multicolumn{8}{|c|}{ Experimental group $(\mathrm{n}=\mathbf{3 0})$} \\
\hline & & \multicolumn{2}{|c|}{ Pre test } & \multicolumn{2}{|c|}{ Post test } & \multirow[b]{2}{*}{ Df } & \multirow[b]{2}{*}{ 't' } & \multirow[b]{2}{*}{$\mathbf{n}$} & \multicolumn{2}{|c|}{ Pre test } & \multicolumn{2}{|c|}{ Post test } & \multirow[b]{2}{*}{ df } & \multirow[b]{2}{*}{ ' $t$ ' } \\
\hline AGE & $\mathbf{n}$ & Mean & SD & Mean & SD & & & & Mean & SD & Mean & SD & & \\
\hline $18-20$ & 28 & 17.79 & 2.587 & 17.39 & 2.025 & 27 & .115 & 26 & $\begin{array}{c}17.1 \\
5\end{array}$ & $\begin{array}{c}2.64 \\
9\end{array}$ & 26.81 & $\begin{array}{c}3.00 \\
7\end{array}$ & 25 & .109 \\
\hline$\overline{21-23}$ & 2 & 18.00 & .000 & 18.00 & 1.414 & 1 & .414 & 4 & $\begin{array}{c}17.0 \\
0\end{array}$ & $\begin{array}{c}2.44 \\
9\end{array}$ & 28.50 & $\begin{array}{c}2.51 \\
7\end{array}$ & 3 & $\begin{array}{c}1.06 \\
5\end{array}$ \\
\hline & & $\mathrm{df}$ & $\mathrm{F}$ & Df & \multicolumn{2}{|l|}{$\mathrm{F}$} & \multicolumn{2}{|c|}{ df } & \multicolumn{2}{|c|}{$\mathrm{F}$} & $\mathrm{df}$ & \multicolumn{3}{|c|}{$\mathrm{F}$} \\
\hline \multicolumn{2}{|c|}{$\begin{array}{l}\text { Between } \\
\text { group }\end{array}$} & 1 & & 1 & & & \multicolumn{2}{|c|}{1} & & 1 & & & \\
\hline \multicolumn{2}{|c|}{$\begin{array}{l}\text { Within the } \\
\text { group }\end{array}$} & 28 & $4.840^{\mathrm{NS}}$ & 28 & $.757^{\mathrm{NS}}$ & & \multicolumn{2}{|c|}{28} & \multicolumn{2}{|c|}{$1.772^{\mathrm{NS}}$} & 28 & \multicolumn{3}{|c|}{.306} \\
\hline Maximu & $\mathrm{sco}$ & $=35$ & & $\mathrm{NS}=$ & Jon $\mathrm{Si}$ & & & & & & & & & \\
\hline
\end{tabular}


Table.6 Comparison of Pre and Post Test Mean Knowledge Score on basic life support in Control and Experimental Group according to habitat

\section{KNOWLEDGE SCORE}

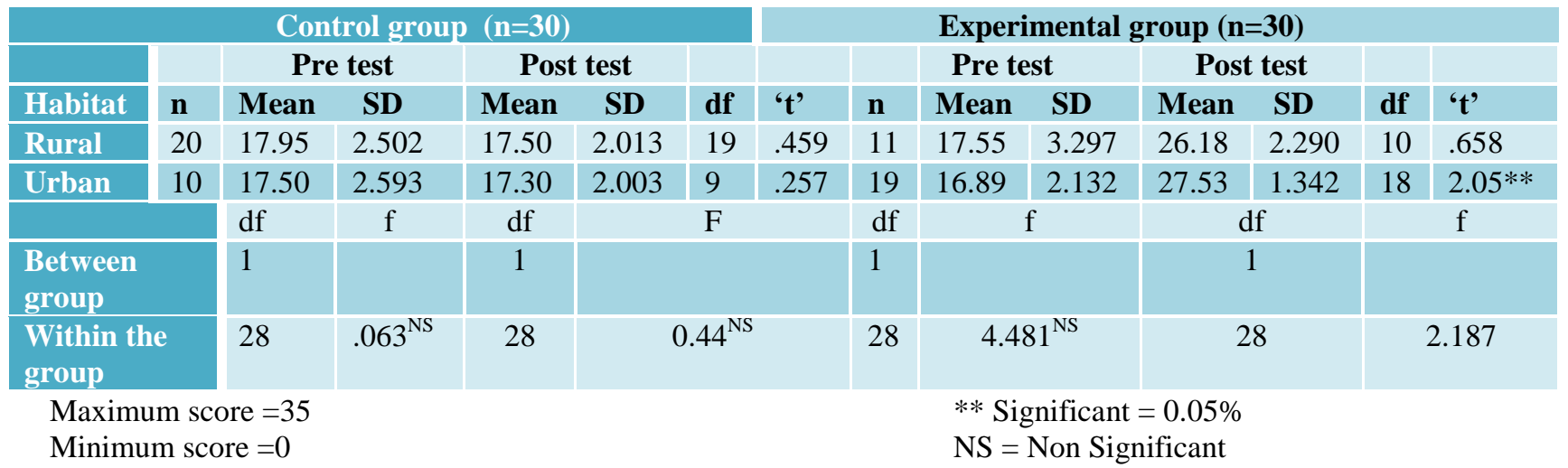

Table.7 Comparison of Pre and Post Test Mean Knowledge Score regarding basic life support among nursing students in Control and Experimental Group according to clinical posting

$\mathrm{N}=60$

\begin{tabular}{|c|c|c|c|c|c|c|c|c|c|c|c|c|c|c|}
\hline \multicolumn{15}{|c|}{ KNOWLEDGE SCORE } \\
\hline \multicolumn{7}{|c|}{ Control group $(n=30)$} & \multicolumn{8}{|c|}{ Experimental group $(n=30)$} \\
\hline & & \multicolumn{2}{|c|}{ Pre test } & \multicolumn{2}{|c|}{ Post test } & \multirow[b]{2}{*}{ df } & \multirow[b]{2}{*}{ 't $t$ ' } & \multirow[b]{2}{*}{$\mathrm{n}$} & \multicolumn{2}{|c|}{ Pre test } & \multicolumn{2}{|c|}{ Post test } & \multirow[b]{2}{*}{ df } & \multirow[b]{2}{*}{ 't' } \\
\hline $\begin{array}{l}\text { Clinical } \\
\text { posting }\end{array}$ & $\mathrm{N}$ & Mean & SD & Mean & SD & & & & Mean & SD & Mean & SD & & \\
\hline $\begin{array}{l}\text { Private } \\
\text { hospital } \\
\end{array}$ & 30 & 17.80 & 2.50 & 17.43 & 1.98 & 29 & $.80 \mathrm{NS}$ & - & - & - & - & - & - & - \\
\hline $\begin{array}{l}\text { Government } \\
\text { hospital }\end{array}$ & - & - & - & - & - & - & - & 30 & 17.13 & 2.58 & 27.03 & 2.97 & 29 & $15.05 * *$ \\
\hline $\begin{array}{l}\text { Maximum } \\
\text { Minimum }\end{array}$ & $\begin{array}{l}\text { core } \\
\text { core }\end{array}$ & & & & $\begin{array}{l}* * \mathrm{Si} \\
\mathrm{NS}=\end{array}$ & & $\begin{array}{l}\mathrm{nt}=0.0 \\
\text { ignifica }\end{array}$ & & & & & & & \\
\hline
\end{tabular}

Table.8 Comparison of Pre and Post Test Mean Knowledge Score regarding basic life support among nursing students in Control and Experimental Group according to area of exposure

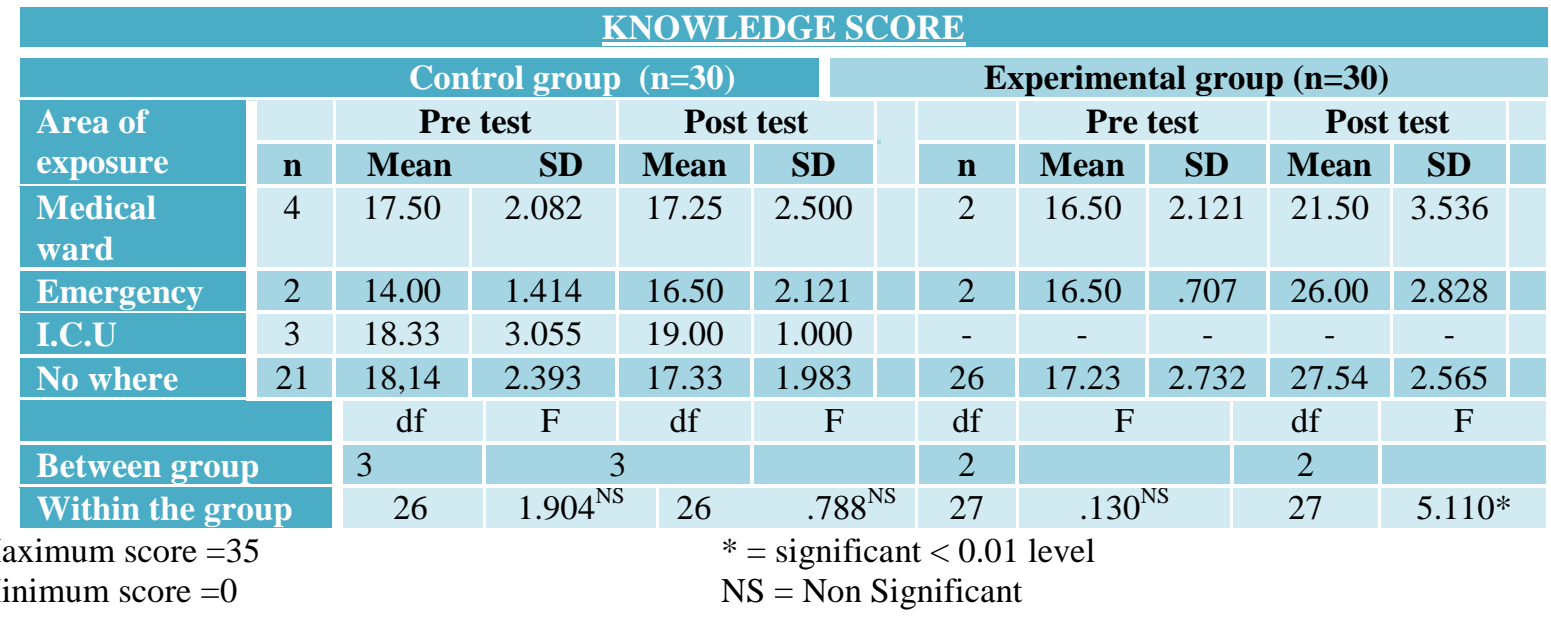


Table.9 Comparison of Pre and Post Test Mean Knowledge Score regarding basic life support among nursing students in Control and Experimental Group according to duration of clinical exposure

$\mathrm{N}=60$

\section{Knowledge score}

\begin{tabular}{|c|c|c|c|c|c|c|c|c|c|c|c|c|c|c|}
\hline \multirow{3}{*}{$\begin{array}{l}\text { Duration } \\
\text { of clinical } \\
\text { Exposure }\end{array}$} & \multicolumn{7}{|c|}{ Control group $(\mathbf{n}=\mathbf{3 0})$} & \multicolumn{7}{|c|}{ Experimental group $(\mathbf{n}=30)$} \\
\hline & \multirow[t]{2}{*}{$\mathbf{n}$} & \multicolumn{2}{|c|}{ Pre test } & \multicolumn{2}{|c|}{ Post test } & \multirow[t]{2}{*}{ df } & \multirow[t]{2}{*}{ ' $t$ ' } & \multirow[t]{2}{*}{$\mathbf{n}$} & \multicolumn{2}{|c|}{ Pre test } & \multicolumn{2}{|c|}{ Post test } & \multirow[t]{2}{*}{ df } & \multirow[t]{2}{*}{ ' $t$ ' } \\
\hline & & Mean & SD & Mean & SD & & & & Mean & SD & Mean & SD & & \\
\hline $\begin{array}{l}4-6 \\
\text { months }\end{array}$ & - & - & - & - & - & & & 30 & 17.13 & 2.58 & 27.03 & 2.97 & 29 & $15.05 * *$ \\
\hline $\begin{array}{l}7-9 \\
\text { months }\end{array}$ & 30 & 17.80 & 2.50 & 17.43 & 1.98 & 29 & $.80^{\mathrm{NS}}$ & - & - & - & - & - & - & - \\
\hline $\begin{array}{l}\text { Maximu } \\
\text { Minimun }\end{array}$ & or & & & & & & $\begin{array}{l}\text { Signi } \\
\mathrm{S}=\mathrm{No}\end{array}$ & $\begin{array}{l}\text { ant } \\
\text { Sig }\end{array}$ & $\begin{array}{l}0.05 \% \\
\text { ficant }\end{array}$ & & & & & \\
\hline
\end{tabular}

Table.10 Comparison of Pre and Post Test Mean Knowledge Score regarding basic life support among nursing students in Control and Experimental Group according to Source of Information

$\mathrm{N}=60$

\begin{tabular}{|c|c|c|c|c|c|c|c|c|c|c|}
\hline \multicolumn{11}{|c|}{ KNOWLEDGE SCORE } \\
\hline \multirow{3}{*}{$\begin{array}{l}\text { Source of } \\
\text { Information }\end{array}$} & \multicolumn{5}{|c|}{ Control group $(\mathbf{n}=\mathbf{3 0})$} & \multicolumn{5}{|c|}{ Experimental group $(n=30)$} \\
\hline & \multirow[t]{2}{*}{$\mathbf{n}$} & \multicolumn{2}{|c|}{ Pre test } & \multicolumn{2}{|c|}{ Post test } & \multirow[t]{2}{*}{$\mathbf{n}$} & \multicolumn{2}{|c|}{ Pre test } & \multicolumn{2}{|c|}{ Post test } \\
\hline & & Mean & SD & Mean & SD & & Mean & SD & Mean & SD \\
\hline Curriculum\teacher & 21 & 17.81 & 2.657 & 17.57 & 1.938 & 23 & 17.35 & 2.587 & 27.00 & 2.505 \\
\hline Health personnel & 5 & 18.20 & 1.789 & 17.00 & 2.828 & 3 & 16.00 & 4.359 & 30.00 & 3.464 \\
\hline Mass media & 4 & 17.25 & 2.872 & 17.25 & 1.258 & 4 & 16.75 & .957 & 25.00 & 4.082 \\
\hline & & df & $\mathrm{f}$ & Df & $\mathrm{f}$ & & df & $\mathrm{f}$ & df & $\mathrm{f}$ \\
\hline Between group & & 2 & & 2 & & & 2 & & 2 & \\
\hline Within the group & & 27 & $0.152^{\mathrm{NS}}$ & 27 & $0.178^{\mathrm{NS}}$ & & 27 & $0.395^{\mathrm{NS}}$ & 27 & 2.736 \\
\hline $\begin{array}{l}\text { Maximum score }=35 \\
\text { Minimum score }=0\end{array}$ & & & & $\begin{array}{l}*= \\
\mathrm{NS}\end{array}$ & ficant & & & & & \\
\hline
\end{tabular}

In experimental group, the pre -test mean knowledge score was 17.13 who were going to government hospital for clinical posting and post -test mean knowledge score was 27.03. The difference between pre and posttest mean knowledge score of experimental group was statistically significant at $\mathrm{p}<0.05$ and $\mathrm{p}<0.01$ level. Hence, clinical posting does not have any effect on knowledge score of nursing students but structured teaching programme had a definite influence on their knowledge regarding basic life support.

Table 8and fig 8:- illustrate that in control group, (18.14) pre-test mean knowledge score among nursing students was obtained by who were not exposed to basic life support in clinical area. pre-test mean knowledge score among nursing students were obtained by 3 nursing students (18.33), who are exposed to basic life support in intensive care unit followed by (17.50) 3 in medical ward and (14.00) 2 in emergency,

In post -test, maximum (17.33) mean knowledge score among nursing students was obtained by 21 nursing students who were not exposed to basic life support in clinical area. (19.00) mean knowledge score among nursing students was obtained by 3 nursing students who were exposed to basic life support in intensive care unit, followed by 4 nursing students (17.25) in medical ward and 2 nursing students (16.50) in emergency 
In experimental group, the maximum (17.23) pre-test mean knowledge score among nursing students was obtained by who were not exposed to basic life support in clinical area. (16.50) mean knowledge score among nursing students were obtained by 2 nursing students who were exposed to basic life support in medical ward as well as in emergency. In post- test maximum (27.54) mean knowledge score among nursing students who were not exposed to basic life support in clinical area, (26.00) mean knowledge score among nursing students who are exposed to basic life support in emergency, (21.50) 2 nursing students in medical ward.

The difference among pre and post -test mean knowledge score was found statistically nonsignificant at $\mathrm{p}<0.05$ level in control group and in experimental group the difference among pre and post -test mean knowledge score was found statistically significant at $\mathrm{p}<0.05$ level computed by ANOVA. Hence it is inferred that area of exposure had definite impact on nursing students regarding basic life support but structured teaching programme had a definite influence on their knowledge regarding basic life support.

Table 9and fig. 9:-delineate that in control group pre -test mean knowledge score of nursing students was 17.80 who were taking 7- 9 month duration of clinical exposure and post -test mean knowledge score was 17.43. The difference between pre and post- test mean knowledge score of control group was statistically non- significant at $\mathrm{p}<0.05$ level.

In experimental group, the pre -test mean knowledge score was 17.13 who were taking 4-6 month duration of clinical exposure and post -test mean knowledge score was 27.03. The difference between pre and post- test mean knowledge score of experimental group was statistically significant at $p<0.05$ level.
Hence, duration of clinical exposure had impact on knowledge score of nursing students but structured teaching programme had a great influence on their knowledge regarding basic life support.

Table 10 and fig. 10 :- explicit that in control group, highest 18.20 pre -test mean knowledge score was obtained by nursing students who got information from health personnel, 17.81 from curriculum $\backslash$ teachers, 17.25 from mass media respectively.

In post-test maximum 17.57 mean knowledge score was obtained by nursing students who had curriculumlteacher as source of information, 17.25 from mass media and 17.00 from health personnel respectively.

The difference between the pre-test and posttest of knowledge score was statistically nonsignificant at $p<0.05$ level.

The difference among the pre -test and posttest of mean knowledge score regarding basic life support of nursing students was found statically non -significant at $\mathrm{p}<0.05$ level as calculated by ANOVA.

In experiment group, the highest 17.35 pre test mean knowledge score was obtained by nursing students who had curriculum/teachers as source of information, 16.75 from mass media and 16.00 from health personnel respectively. In posttest maximum 30.00 mean knowledge score was obtained by nursing students who had health personnel as source of information, 27.00 from curriculumlteacher and 25.00 from mass media respectively.

The difference among the pre -test and posttest of mean knowledge score regarding basic life support of nursing students was found statically non -significant at $\mathrm{p}<0.05$ level as calculated by ANOVA. 
Hence, it was adjudged that source of information does not have any effect on knowledge score of nursing students but structured teaching programme had a definite influence on their knowledge regarding basic life support

\section{Results and Discussion}

This chapter relate the findings of the present study to the studies done earlier, the finding of the present study have been discussed in accordance with the objective of this study.

The first objective of the study to assess pretest knowledge score regarding basic life support among nursing students in control and experimental group. The pre- test mean knowledge score in control and experimental group was $(17.80,17.13)$ respectively. Majority (50\%-75\%) of nursing student both in the control and experimental group had average pretest knowledge regarding basic life support.

Second objective was to assess the post -test knowledge score regarding basic life support among nursing students in control and experimental group. Post - test mean knowledge score in control group and experimental group was $(17.43,27.03)$ respectively. In control group, post- test majority of (77.34\%) 22 nursing students had average knowledge score In experimental group majority of $20(66.66 \%)$ nursing students had good knowledge score and $4(13.34 \%)$ had excellent posttest knowledge regarding basic life support.

Austin (2002) ${ }^{73}$ conducted An experimental study about CPR knowledge score among nurses in Fedrico Hospital in New York found that the pretest knowledge was around 52\% which is increased to $96 \%$ in posttest. These findings are more and less similar to the findings of the present study.
Analysis of the third objective of the study i.e. to compare the pre-test and post-test knowledge score regarding basic life support among nursing students in control and experimental group. Revealed that the difference between pretest mean knowledge score of both control group and experimental group was statistically non- significant at $\mathrm{p}<$ 0.05 level. However the difference between posttest mean knowledge score of both control group and experimental group was statistically significant at $p<0.05$ level. Hence research hypothesis was accepted that post test score of experimental group will be significantly higher than knowledge score of control group

Prociuk (2003) ${ }^{74}$ study reported that nurse's knowledge on CPR reveals that proper training and certification programme increased the knowledge of nurses on CPR.

Arnold broom (2002) ${ }^{75}$ study findings was reported that by using a planned teaching approach on CPR among nurses reveals $48 \%$ differences in mean percentage of post test score $(97 \%)$. These findings were more or less similar to the present study findings.

Analysis of fourth objective of the study i.e. To find out the relationship between the pretest and post-test knowledge score regarding basic life support among nursing students in control and experimental group with selected variables i.e. age, habitat, clinical posting, area of clinical exposure to B.L.S, duration of Clinical Exposure and Source of Information.

Analysis of finding related to age showed that maximum 17.79 pre-test mean knowledge score among nursing students was obtained by age group of 18-20 years, 18.00 in 21-23 years. And in post-test 17.39 mean knowledge score among nursing students was obtained by 18- 20 years, and 18.00 in 21-23 years respectively. In experimental group maximum 
17.15 pre-test mean knowledge score among nursing students was obtained by age group of $18-20$ years, 17.00 in 21-23 years. And in post-test 28.50 mean knowledge score among nursing students was obtained by 21-23 years, and 26.81 in 18- 20 years. Hence it is inferred that age had no impact on knowledge among nursing students in various age groups.

Analysis of finding related to habitat in control group, maximum (17.95) pre-test mean knowledge score among nursing students was obtained who belonged from rural area, (17.50) from urban area. And in post-test (17.50) mean knowledge score among nursing students was obtained who belonged to rural area and (17.30) from urban area.

In experimental group maximum (17.55) pretest mean knowledge score among nursing students was obtained, who belonged from rural area, (16.89) from urban area. And in post-test (26.18) mean knowledge score among nursing students was obtained who belonged to rural area and (27.53) from urban area.

Analysis of finding related to clinical posting in control group pre -test mean knowledge score of nursing students (17.80) who were going to private hospital for clinical posting and post -test mean knowledge score was 17.43

In experimental group, the pre -test mean knowledge score was 17.13 who were going to government hospital for clinical posting and post -test mean knowledge score was 27.03 .

Hence, clinical posting does not have any effect on knowledge score of nursing students but structured teaching programme had a great influence on their knowledge regarding basic life support.
Analysis of finding related to area of exposure to basic life support in control group, (18.14) pre-test mean knowledge score among nursing students was obtained by who were not exposed to basic life support in clinical area. (17.50) pre-test mean knowledge score among nursing students were obtained by, who were exposed to basic life support in medical ward, (14.00) in emergency, (18.33) in intensive care unit. In post -test, maximum (17.33) mean knowledge score among nursing students was obtained by who were not exposed to basic life support in clinical area.(19.00) mean knowledge score among nursing students was obtained by who were exposed to basic life support in intensive care unit, (16.50) in emergency, (17.25) in medical ward.

In experimental group, the (17.23) pre-test mean knowledge score among nursing students was obtained, who were not exposed to basic life support in clinical area. (16.50) mean knowledge score among nursing students were obtained who were exposed to basic life support in medical ward and in emergency. In post- test maximum (27.54) mean knowledge score among nursing students who were not exposed to basic life support in clinical area, (26.00) mean knowledge score among nursing students who were exposed to basic life support in emergency, (21.50) in medical ward. Hence it is inferred that area of exposure had impact on nursing students but structured teaching programme had a great influence on their knowledge regarding basic life support

Analysis of finding related to duration of clinical exposure that in control group pre test mean knowledge score of nursing students (17.80) who were taking 7-9 month duration of clinical exposure and post -test mean knowledge score was 17.43. In experimental group, the pre -test mean knowledge score was 17.13 who were taking 
4-6 month duration of clinical exposure and post -test mean knowledge score was 27.03

Analysis of finding related to source of information, in control group, highest (18.20) pre -test mean knowledge score was obtained by nursing students who had health personnel as source of information, (17.81) curriculum। teachers, (17.25) from mass media respectively. In post-test maximum (17.57) mean knowledge score was obtained by nursing students who had curriculumlteacher as source of information, (17.25) from mass media and (17.00) from health personnel respectively. In experiment group, the highest (17.35) pre -test mean knowledge score was obtained by nursing students who had curriculum/teachers as source of information, (16.75) from mass media and (16.00) from health personnel respectively. In posttest maximum (30.00) mean knowledge score was obtained by nursing students who had health personnel as source of information, (27.00) from curriculumlteacher and (25.00) from mass media respectively.

Hence, it was adjudged that source of information does not have any effect on knowledge score of nursing students but structured teaching programme had a great influence on their knowledge regarding basic life support

Christofer, D (2007) ${ }^{76}$ A quasi experimental study revealed that, there is a significant association of knowledge with age and experience of staff nurses. Age increases their knowledge gain store also increases their years of experience increases knowledge score in experimental group. In control group, out of the several demographic variables, knowledge gain on CPR is not associated with demographic variables.

Phipps, Monahin, Sands, Marck and Neighbors, Cardio pulmonary resuscitation:
Medical Surgical Nursing 7th edition, Mosby Publications, page no 701.

\section{References}

Araujo S, de Almeida AO, Araújo IE, Dalri $\mathrm{MC}$, Theoretical knowledge of nurses working in non-hospital urgent and emergency care units concerning cardiopulmonary arrest and resuscitation. Rev Lat Am Enfermagem. 2011 Mar-Apr; 19(2): 261-8. PMID: 21584371 [PubMed - indexed for MEDLINE]

Arnold broom "Advanced Emergency care" 4th edition, Lippincott publishers, Philadelphia, 2002. P. No. 127-129.

Christofer daisy "study to assess the effectiveness of structure teaching programme on knowledge and skills of CPR among staff nurses working in selected hospitals, Hassan, 2007. [pubmed.com]

Introduction to the cardio vascular system, introduction to the heart. Www.google.com

Prociuk 'CPR and Nurses', Journal of clinical nurse specialist, 2003, Dec (12): 23: 6264

Walsh mike, "Watson's clinical nursing and related sciences", 6th edition. Balliere Tindali Publishers, Edinburgh, 2004. PP: 307-310.

White L, Rogers J, Bloomingdale M, Fahrenbruch C, Culley L, Subido C, Eisenberg M, Rea T, Dispatcherassisted cardiopulmonary resuscitation: risks for patients not in cardiac arrest, American Journal of Resuscitation, 2010 Jan 5;121(1): 91-5

World Health Organization Statistical Information System (WHOSIS). Cardiovascular Disease Statistics. Available inhttp://www3.who.int/whosis/menu.cfm. 


\section{How to cite this article:}

Priyanka Chaudhary. 2018. A study on Effectiveness of Structured Teaching among Nursing Students. Int.J.Curr.Microbiol.App.Sci. 7(06): 1833-1849.

doi: https://doi.org/10.20546/ijcmas.2018.706.219 